\title{
SURAU SULUK, MURSYID DAN PENGOBATAN TRADISIONAL DI KABUPATEN LIMA PULUH KOTA
}

\author{
SURAU SULUK, MURSYID AND TRADITIONAL THERAPY \\ IN LIMA PULUH KOTA REGENCY
}

\author{
Hariadi \\ Balai Pelestarian Nilai Budaya Sumatera Barat \\ Jl. Raya Belimbing No.16 A, Kuranji, Padang \\ E-mail:h.adi22@yahoo.co.id
}

\begin{abstract}
Abstrak
Surau Suluk mempunyai satu sisi yang jarang diungkap yaitu tentang aktifitas pengobatan yang dilakukan oleh Mursyid. Tulisan ini menjelaskan praktik pengobatan tradisional yang dilakukan oleh Mursyid suluk di Surau-Surau Suluk yang terdapat di Kabupaten Lima Puluh Kota Sumatera Barat. Penelitian ini adalah penelitian kwalitatif deskriptif dengan teknik pengumpulan data studi pustaka, observasi dan wawancara. Informan pada penelitian ini adalah beberapa orang Mursyid yang berasal dari surausurau suluk dan juga orang-orang yang terlibat langsung dalam aktifitas di Surau Suluk serta pengobatannya. Hasil analisis data menunjukkan bahwa pengobatan tradisional yang dilakukan oleh Mursyid di Surau Suluk bertumpu kepada zikrulloh. Penyakit yang diobati adalah penyakit medis dan non-medis, namun penyakit non-medis lebih banyak ditangani, seperti penyakit yang disebabkan gangguan jin.
\end{abstract}

Kata kunci: Mursyid, Surau Suluk, Pengobatan tradisional

\begin{abstract}
Medicinal treatment or therapy by Mursyid is another side of Surau suluk (Suluk mosque) that is studied rarely. This study aims to explain the traditional therapy done by Mursyid in suluk mosques in Lima Puluh Kota regency, West Sumatera. This research used descriptive qualitative approach. The data were collected by doing literature review, field observation, and in-depth interview. The informants were several Mursyid from some suluk mosques and also the people who get involved in suluk activities and therapy. The result of data analysis explained that traditional therapy done by Mursyid in suluk mosques are based on zikrulloh. The therapy is done on medical and non medical diseases, however, it is focused more on non medical diseases such as possession of the jin (evil spirit).
\end{abstract}

Key words: Mursyid, Suluk mosques, Traditional medicinal treatment (therapy) 


\section{PENDAHULUAN}

Kata Surau adalah sebutan khas bagi masyarakat Minangkabau untuk menyebut tempat belajar agama dan beribadah. Menurut beberapa tulisan istilah surau sudah dikenal sebelum Islam masuk ke Minangkabau. Ada yang berpendapat bahwa surau pertama kali didirikan masa jayanya kekuasaan Adytyawarman di Minangkabau. Datangnya agama Islam dan meredupnya kekuasaan Adytyawarman menjadikan surau berobah fungsi menjadi pusat pembelajaran Islam (Akhiruddin 2015: 211). Beberapa surau tumbuh menjadi pusat pembelajaran tarekat, seperti Tarekat Naqsyabandiyah. Bagi masyarakat, surau tersebut biasa di sebut surau suluk, karena ada aktifitas khalwat disurau tersebut yang lebih populer dengan sebutan bersuluk.

Surau Suluk merupakan pusat pembelajaran dan ibadah bagi kaum muslimin yang pengamalan keagamaanya menganut corak Tarekat Naqsyabandiyah. Agama Islam bercorak Tarekat Naqsyabandiyah telah menjadi pengamalan keagamaan di Kabupaten Lima Puluh Kota Sumatera Barat. Mengenai masukknya Tarekat ini menurut Azyumardi Azra di bawa oleh Jamal al-din seorang Minangkabau pada paruh pertama abad ke 17 (Azra 2004:369). Hubungan penganut Tarekat Naqsyabandiyah di nusantara, termasuk dari Minangkabau dengan pusat Tarekat Naqsyabandiyah Makkah sebelum abad ke 20 terus berlangsung. Jabal Abi Qubais merupakan tempat penting bagi penganut Tarekat Naqyabandiyah di Nusantra. (Bruinessen 2007:225).

Berdasarkan keterangan Dobbin (2008:196), salah satu daerah yang yang pertumbuhan pengikut Tarekat Naqsyabandiyah yang cukup menonjol akhir abad ke 18 yang terdapat di Lima Puluh Kota adalah di daerah Taram. Sampai saat ini pusat Tarekat Naqsyabandiyah tersebut masih banyak diziarahi oleh para pengikut Tareqat Naqsyabandiyah.

Dalam perjalanannya, di beberapa Surau Suluk, disamping diajarkan metode pendekatan diri kepada Allah dengan metode zikir, surau juga berkembang menjadi pusat pengobatan tradisional. Mursyid Suluk yang memberikan bimbingan ibadah dan bimbingan rohani juga menjadi praktisi pengobatan tradisional untuk berbagai jenis penyakit, baik yang medis maupun yang non medis.

Pada era tahun 70 an sampai 2000 Mursyid Suluk yang terkenal dengan pengobatan tradisionalnya diantaranya adalah Buya Haji Amin di Taeh Bukit, Datuak Angso di daerah 
Tanjung Pati, dan Buya Jalinus di Tabek Panjang Koto Baru Simalanggang. Saat ini (2017) praktik pengobatan tradisional di Surau Suluk dapat ditemukan diantaranya di Surau Suluk Buya Zed di Koto Tuo Mungka, di Suluk Ongku Boncah di Nagari Taeh, di Surau Suluk Buya Edison Kasim di Sarilamak Tanjuang Pati dan di Surau Suluk Buya Belubus di Belubus dan di beberapa Surau Suluk lainnya.

Berdasarkan fenomena di atas tulisan ini mengungkapkan keberadaan Surau Suluk, kehidupan para mursyid, dan praktik pengobatan tradisional di Surau Suluk di Kabupaten Lima Puluh Kota. Keberadaan surau suluk tersebut diungkap melalui beberapa pertanyaan seperti bagaimana keberadaan Surau Suluk dan Mursyid Suluk dan bagaimana praktik pengobatan tradisional yang dilakukan oleh Mursyid Suluk di Kabupaten Lima Puluh Kota.

\section{METODE PENELITIAN}

Untuk menghindari kekeliruan dalam memahami beberapa istilah dalam tulisan ini, berikut dijelaskan beberapa hal berikut: pertama Surau. Kata surau ada yang berpendapat berasal dari kata dalam bahasa Arab, yaitu sugra yang berarti kecil. Karena pengaruh dialek berubah sebutan menjadi surau, yang berarti bangunan lebih kecil dari masjid. Surau pertama yang dikenal adalah surau Ulakan Pariaman yang didirikan oleh Syekh Burhanuddin Ulakan (16461691). Surau-surau yang ada mempunyai karekteristik masing-masing bila dipandang dari keilmuan yang diajarkan ada surau yang mengajarkan ilmu-ilmu syariat dan ada juga yang mengajarkan ilmu tarekat. Suluk. Berarti menempuh jalan spritual menuju Alloh. Menempuh jalan suluk (bersuluk) mencakup sebuah disiplin seumur hidup dalam melaksanakan aturanaturan eksoteris agama Islam (syariat) sekaligus aturan-aturan esoteris agama Islam (hakikat). Bersuluk juga mencakup hasrat untuk mengenal diri, memahami esensi kehidupan, pencarian tuhan dan pencarian kebenaran sejati (ilahiyyah) melalui penempaan diri seumur hidup dengan melakukan syariat lahiriyah sekaligus syariat bathiniah demi mencapai kesucian hati untuk mengenal diri dan tuhan.

Dengan demikian, surau suluk yang dimaksud adalah tempat yang digunakan untuk melaksanakan pembelajaran berzikir dan praktih mengenal diri, memahami esensi kehidupan, pencarian tuhan dan pencarian kebenaran sejati (ilahiyyah) melalui penempaan diri seumur hidup dengan melakukan syariat lahiriyah sekaligus syariat bathiniah demi mencapai kesucian 
hati untuk mengenal diri dan tuhan.

Mursyid Adalah sebutan untuk seorang guru pembimbing dalam dunia thoriqoh yang telah memperoleh izin dan ijazah dari guru mursyid di atasnya yang terus bersambung sampai kepada guru mursyid shohibuttoriqoh yang musalsal dari rasul SAW untuk mentalqin zikir/ wirid thoriqoh kepada orang orang yang datang meminta bimbingannya (murid).

\section{Pengobatan Tradisional}

Menurut WHO (2000) pengobatan tradisional adalah jumlah total pengetahuan, keterampilan dan praktek-praktek yang berdasarkan pada teori - teori, keyakinan dan pengalaman masyarakat yang mempunyai adat budaya yang berbeda, baik dijelaskan atau tidak, digunakan dalam pemeliharaan kesehatan serta dalam pencegahan, diagnosa, perbaikan dan pengobatan penyakit secara fisik dan juga mental.

Mengenai pembagian pengobatan tradisional, Asmino (1995) menjelaskan bahwa pengobatan tradisional terbagi menjadi dua, yaitu cara penyembuhan tradsional atau traditional healing yang terdiri dari pijatan, kompres, akupuntur dan sebagainya dan obat tradisional atau traditional drugs yaitu menggunakan bahan-bahan yang tersedia dari alam sebagai obat yang menyembuhkan penyakit. Obat tradisional ini terdiri dari tiga jenis, yaitu pertama dari sumber nabati yang diambil dari bagian-bagian tumbuhan seperti buah, daun kulit, batang dan sebagainya. Kedua obat yang diambil dari sumber hewani seperti bagian kelenjer-kelenjer, tulang-tulang maupun dagingnya dan yang ketiga adalah dari sumber mineral atau garam garam yang bisa didapatkan dari mata air yang keluar dari tanah, contohnya air mata air zam zam yang terletak di makkah mukarromah.

Kekhasan pengobatan tradisional yang dilakukan oleh mursyid di surau suluk adalah penekanan pada kekuatan spritual dan doa yaitu kekuatan dari zikrulloh yang senantiasa terasah. Menurut Ongku Boncah, seorang sakit yang senantiasa zikrulloh akan lebih mudah sembuhnya dengan izin Allah bila dibandingkan seorang sakit yang tidak zikrulloh, hal tersebut terjadi karena pertolongan pengobatan dari seorang mursyid akan mendapat tempat pada diri orang sakit yang senantiasa zikrulloh, hal seperti itu tidak terjadi pada orang sakit yang tidak zikrulloh.

Penelitian ini adalah penelitian kualitatif deskriptif. Penggunaan model penelitian ini untuk mengungkapkan dan menganalisis proses-proses sosial dan makna yang terdapat pada fenomena yang tampak di permukaan. Model penelitian ini tidak hanya menjelakan fakta tapi 
juga proses dan makna dibalik fakta (Bungin 2007:144). Teknik pengumpulan data dari kegiatan penelitian ini adalah sebagai berikut: Pertama. Studi kepustakaan, merupakan aktifitas mengumpulkan tulisan-tulisan yang berkaitan dengan topik bahasan yang tersebar di pelbagai pustaka ataupun koleksi pribadi. Bentuk-bentuk dokumen yang akan dikumpulkan adalah buku, majalah, artikel, koran, foto dan dokumen-dokumen lainnya. Kedua. Pengamatan (observasi), merupakan teknik pengumpulan data dengan cara mengamati, meneliti atau mengukur kejadian yang sedang berlangsung, menggunakan metode ini, data yang diperoleh adalah data yang faktual dan aktual, sehingga data yang diperoleh pada saat peristiwa berlangsung. Ketiga. Wawancara, merupakan proses interaksi dan komunikasi antara peneliti dengan informan. Wawancara juga dapat diartikan sebagai model pengumpulan data dengan cara bertanya langsung kepada informan dan jawaban-jawaban dicatat atau direkam dengan alat bantu perekaman (Kusmayadi 2000:84$85)$.

Langkah-langkah pengolahan data sebagai berikut: mengorganisasikan data, memilah data menjadi satuan, mensintesiskan, mencari dan menemukan pola, dan menemukan apa yang penting dan apa yang perlu dipelajari dan terakhir memutuskan apa yang dapat dan perlu diceritakan kepada orang lain (Wiranta dan Hadisuwarno 2007:15-16).

Penelitian ini dilaksanakan di Kabupaten Lima Puluh Kota. Setelah melakukan survey pendahuluan penelitian, peneliti mendapatkan informasi dari Apria Putra ${ }^{1}$ terdapat sekitar 120 buah Surau Suluk di Kabupaten Lima Puluh Kota.(Wawancara dengan Apria Putra pada hari Sabtu tanggal 25 Maret 2017 di Nagari Taeh). Mengingat banyaknya jumlah Surau Suluk tersebut, maka peneliti akan menjadikan empat buah Surau Suluk sebagai fokus penelitian ini. Surau surau tersebut adalah Surau Suluk Buya Zed, Surau Suluk Ongku Boncah, Surau Suluk Buya Edison Kasim dan Surau Suluk Buya Belubus. Penelitian ini dilaksanakan dalam tahun 2017, mulai bulan Maret sampai bulan Desember. Informan dalam penelitian ini adalah Mursyid Suluk, murid-murid di Surau Suluk, peneliti yang pernah melakukan penelitian berkaitan dengan surau di Kabupaten Lima Puluh Kota dan masyarakat yang pernah berobat ke mursyid di Surau Suluk.

\footnotetext{
${ }^{1}$ Apria Putra adalah peneliti dan dosen di IAIN Bukittinggi. Topik penelitian yang dilakukannya di Kabupaten Lima Puluh Kota berkaitan dengan sejarah surau, ulama ulama surau dan naskah naskah klasik yang tersebar di pelbagai surau yang ada di Kabupaten Lima Puluh Kota Sumatera Barat.
} 


\section{PEMBAHASAN}

\section{Pengobatan tradisional Surau Suluk Buya Zed}

\section{1) Sekilas Kehidupan Buya Zed}

Buya Zed lahir di Mungka 58 tahun yang lalu. Pendidikan formal beliau adalah di sekolah umum, mulai dari tingkat SD, SMP dan SPG. Pada tingkat perguruan tinggi Buya Zed pernah kuliah di ASKI Padang Panjang, Akademi Bahasa Asing (ABA) dan IAIN Imam Bonjol di Padang. Perkuliahan pada tiga perguruan tinggi tersebut tidak ada yang diselesaikannya.

Perhatian terhadap ilmu agama telah terlihat pada diri Buya Zed semenjak kecil, lebih khususnya terhadap tarekat. Untuk memperdalam pelajarannya dalam hal Tarekat Naqyabandiyah Buya Zed mengikuti suluk/khalwat pertama kali di surau Buya Pulai di Mungka dan yang kedua di surau Buya Patiah di Gurun. Buya Zed juga mendalami pengajian tarekat kepada Syekh Haji Amin di Taeh Bukit.

Berbekal pengajian tarekat kepada beberapa orang guru tersebut, Buya Zed mendirikan Surau Suluk pada tahun 1988 di Koto Tuo Mungka. Lokasi surau tersebut terdapat di tepi pesawahan, sekitar seratus meter dari jalan raya Payakumbuh Mungka. Bangunan surau bercat putih yang terbuat dari kayu tersebut terlihat dari jalan raya. Aktifitas mingguan yang dilaksanakan di surau adalah pengajian yang dilaksanakan setiap jumat malam. Sedangkan suluk/khalwat dilaksanakan setiap bulan Puasa.

\section{2) Pengobatan Tradisional}

Buya Zed memulai pengobatan tahun 1977. Menurut beliau tidak ada niat dan rencana untuk membuka praktik pengobatan, hanya saja waktu itu ada orang sakit yang meminta untuk diobati, makanya beliau membantu mengobati dengan zikrulloh. Alloh mentakdirkan orang yang meminta obat tersebut sembuh. Semenjak itulah banyak orang yang datang meminta obat. Pada awalnya pengobatan yang dilakukan belum terbuka seperti saat ini pengobatan yang terang-terangan dimulai tahun 1985. Pengobatan pada awalnya hanya dengan zikrulloh semata, tidak menggunakan ramuan, kalaupun ada hanya sebatas air putih saja. Pengobatan yang menggunakan ramuan dimulai Buya Zed setelah mendapatkan saran dari seorang dosen sewaktu kuliah di Fakultas Ushuluddin IAIN Imam Bonjol Padang agar pengobatan tampak logis maka perlu ada ramuan yang diberikan kepada pasien. (Wawancara dengan Buya Zed pada hari Rabu tanggal 29 Maret 2017 di Koto Tuo Mungka). 
Kebanyakan ramuan pengobatan yang digunakan didapatkan secara laduni (didapat tanpa melalui tahapan belajar) tidak dipelajari dari seorang guru. Penyakit yang ditangani kebanyakannya adalah penyakit non medis, seperti penyakit karena sihir dan penyakit gangguan jin. Jin masuk tubuh manusia ada yang masuk sendiri ada yang dimasukkan orang. Jin yang masuk sendiri ke dalam tubuh manusia adalah ulah iseng, tapi yang dimasukkan oleh kahin atau pesihir, dikirim untuk mendatangkan penyakit kepada seseorang. Dampak jin yang dikirim bermacam macam ada yang sakit perut, sakit kepala, sakit dada, sakit sesak nafas namun penyakit secara medis penyakit tidak ditemukan. Bisanya penyakit seperti itu ada waktu waktunya, kadang pagi, kadang, senja, malam tidak terus menerus. Sekitar 90 persen pasien yang berobat adalah karena penyakit non medis, kalau sakit yang bersifat medis biasanya disarankan berobat ke dokter.

Praktik pengobatan dilaksanakan malam hari mulai siap magrib. Waktu pelaksanaan pengobatan Buya Zed dibantu oleh enam orang, tiga orang di bagian penyedia ramuan dan rempah-rempah, dan tiga orang pada bagian membantu operasional pengobatan.

Menurut Boni, salah seorang asisten Buya Zed, Penyakit yang dikirim atau sihir yang berat menanganinya. Waktu pengobatan terjadi perang tidak nampak, kadang imbasnya kepada para asisten buya. Kalau kita tidak zikrullah sewaktu mengobati penyakit yang disebabkan sihir biasanya akan kena dampaknya. Pernah, beberapa waktu yang lalu saya sampai sepuluh hari sakit, tidak bisa membantu buya, badan terasa dingin, dinginnya dari dalam tubuh, walaupun selimut sampai empat lapis, tetapi dingin tetap terasa. Hal itu karena pertempuran batin antara yang mengobati dengan yang mengirim sihir. Cuma kadang ada yang bisa dihindarkan dan kadang ada yang tidak, karena tingkatan kita baru pemula (salik) sedangkan orang yang mengirim penyakit tersebut sudah tinggi tingkatannya. (Wawancara dengan Boni Purnama pada hari Selasa tanggal 28 Maret 2017 di Koto Nan Ampek).

Jin utusan para dukun tersebut masuk kedalam tubuh, melalui ujung jari kemudian apa yang ditujunya akan terasa sakit, misalnya kepala atau tempat lainnya. Kalau hal itu terjadi dilawan dengan zikirullah. kalau kita kuat gangguannya akan hilang. Namun jika yang datang lebih kuat terkadang zikir yang belum sempurna belum bisa mengusirnya. Jadi harus selalu ingat kepada Allah.

Pengobatan yang dilakukan buya Zed tidak fokus kepada kekuatan ramuan. Ramuan ditujukan supaya pengobatan nampak logis bagi masyarakat umum, bisa dicerna dan bisa dipahami agar tidak menimbulkan fitnah. Boni mengungkapkan 
Kalau sekedar pengobatan dengan zikrullah, sepertinya bagi sebagian orang tidak masuk akal. Hal utama dari pengobatan adalah bagaimana menaklukkan orang yang mengirim sihir penyakit, mengusir jin. Kalaupun ramuan dipakai tetapi jinnya tidak diusir maka penyakitnya tidak akan sembuh. Untuk mempercepat keluarnya jin dari dalam tubuh pasien, tindakan yang dilakuan adalah dengan menggesek ujung jari dengan merica. Ujung jari merupakan tempat masuknya jin. Nampaknya jin tidak suka merica. Kalau sakit non medis akan terasa sakit ujung jari digesek dengan merica, tapi kalau bukan penyakit non medis biasanya tidak sakit. (Wawancara dengan Boni Purnama pada hari Selasa tanggal 28 Maret 2017 di Koto Nan Ampek).

\section{3) Treatmen pengobatan}

Treatmen pengobatan pasien yang sakit jiwa karena gangguan jin yang dilakukan Buya Zed sebagai berikut: Pertama, jin yang berada dalam tubuh pasien di usir. Kedua kalau ada dukun jahat yang mengirim jin itu juga harus ditaklukan. Ketiga, diterapi dengan zikir kullu jasad. Zikir kullu jasad untuk menghantam jin jin yang mengganggu di dalam tubuh pasien. Keempat,terapi pengobatan di tekan ujung ujung jari pasien dengan merica bulat, biasanya pasien merasakan sakit, dan berteriak-teriak hal itu dilakukan selama tiga bulan setiap malam. Obat ramuannya ada yang diminumkan, seperti air tujuh mesjid dan ramuan lannya.

\section{Pengobatan Tradisional di Surau Suluk Ongku Boncah}

\section{1) Sekilas Kehidupan Ongku Boncah}

Ongku Boncah lahir di Taeh Baruah 66 tahun lalu. Nama kecil beliau adalah Alisani. Setelah menamatkan Sekolah Dasar beliau tidak melanjutkan pendidikan formal. Beliau pindah dari satu surau ke surau yang lainnya untuk mempelajari tarekat. Tarekat pertama yang pelajari adalah Tarekat Saman kepada Syekh Haji Amin di Taeh Bukit.

Ongku Boncah mewarisi surau dari buya yang terdahulu. Surau tempat mengajarkan tarekat ini sudah berumur lebih dari seratus tahun. Buya pendiri surau ini meninggal dalam usia 110 tahun. Buya pendiri surau tersebut dikenal dengan sebutan Ongku Boncah Nan Tuo. Sepeninggal Ongku Boncah nan Tuo aktifitas di surau tersebut dilanjutkan oleh dua orang anaknya. Setelah dua orang Ongku Boncah Nan Tuo meninggal, pengelolaan Surau Suluk dilanjutkan oleh Alisani gelar Ongku Boncah, yang dimaksud dalam tulisan ini. Beliau adalah generasi yang ke empat. 


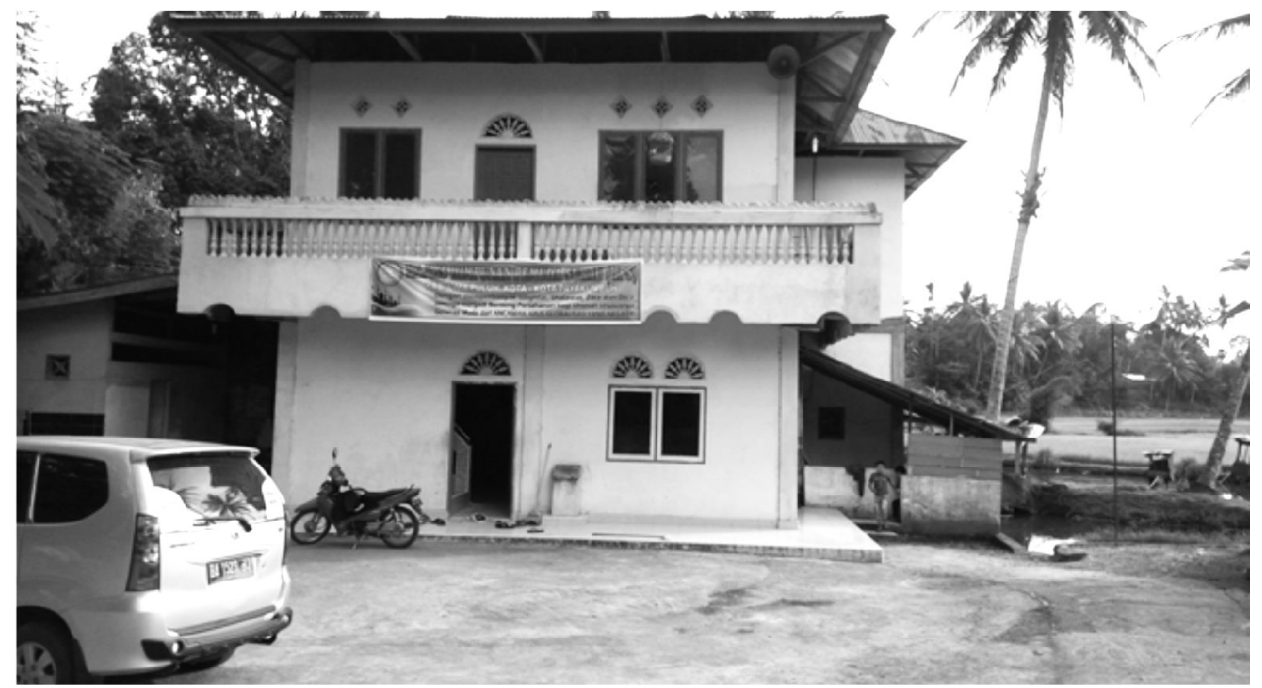

Foto 1: Surau Suluk Ongku Boncah di Taeh Baruah

Bangunan surau ini sudah dua kali diganti, pertama bangunan dari kayu diganti dengan bangunan kayu lagi, dan baru kemudian diganti dengan bangunan terbuat dari batu seperti saat ini. Aktifitas di surau ini ramai di malam hari. Para pemuda belajar Tarekat Saman dan latihan silat dan kegiatan lainnya. Surau ini menjadi pusat kegiatan pemuda. pengisian spiritual dengan tarekat dan fisik dengan belajar silat. Silat dengan tarekat di kombinasikan. Harapannya Para pemuda terbentengi dari hal-hal yang negative.

Setiap jumat, setelah melaksanakan shalat jumat dilaksanakan kegiatan tawajjuh dalam rangka latihan untuk memperdalam pemahaman terhadap zikir. Pada bulan Ramadhan dilaksanakan suluk/khalwat selama empat puluh hari. Peserta yang mengikuti kegiatan berasal dari nagari-nagari yang terdapat di Kabupaten Lima Puluh Kota. Jumlah peserta biasanya dikisaran 20 sampai 30 orang.

\section{2) Pengobatan Tradisional yang dilakukan}

\section{a. Pijit/Urut}

Kemampuan memijit/ mengurut di pelajari oleh Ongku Boncah dari kakeknya waktu masih muda, namun kemudian kemampuan itu bertambah dengan sendirinya. Mengurut tetap digabungkan dengan zikrullah, karena dengan demikian penyembuhan akan cepat dengan izin Allah. 


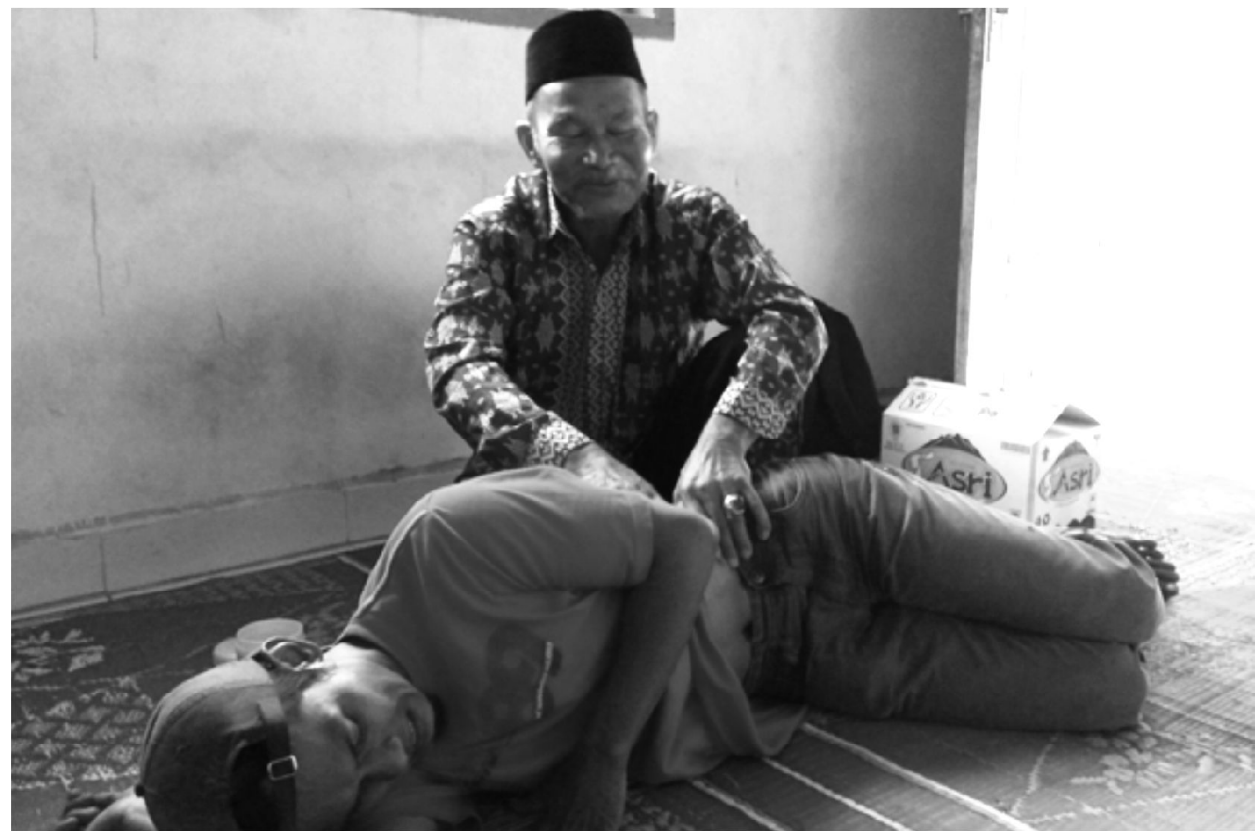

Foto 2: Proses Pengobatan

Menurut Ongku Boncah, pasien yang di dalam dirinya tidak terpatri zikrullah, kalimat laa Ilaha Illalloh akan susah mengobatnya. Sebaliknya bila dalam diri pasien terpatri zikrullah, maka pasien tersebut akan bisa cepat sembuhnya dengan izin Allah. Ibaratkan signal Handphone pada kedua tempatnya ada signal sehigga mudah untuk tersambungnya.

\section{b. Pengobatan Kesurupan Jin}

Untuk menyadarkan orang yang kesurupan jin pengobatan yang dilakukan adalah dengan mengeluarkan jin yang masuk kedalam tubuh seseorang. Pernah terjadi beberapa kejadian berkaitan dengan hal ini. Salah satu kejadian itu sebagai berikut:

Saya diberitahu seorang kemenakan saya yang mengajar sebuah SLTA di Solok melalui telfon bahwa banyak anak muridnya kesurupan. Dia meminta bantuan saya untuk mengobati. Pengobatan saya lakukan lakukan dari jauh. Saya suruh mempersiapkan air dengan dasun. Saya bantu dengan zikrullah dari jauh dengan zikir dalam Tarekat Saman. Air itu dilapkan ke wajah dan tubuh yang kesurupan. Alhamdulillah dengan izin Allah para siswa itu sadar kembali. (Wawancara dengan Ongku Boncah pada hari Sabtu tanggal 25 Maret 2017 di Nagari Taeh).

\section{c. Pengobatan Penyakit Karena Sihir}

Menurut Ongku Boncah untuk pengobatan pasien yang sakitnya karena sihir atau gunaguna cara pengobatan didapatkan dalam berzikir dan ada juga dalam mimpi. Sewaktu 
melaksanakan zikir biasanya datang petunjuk atau ilham. Intinya, pengobatan bukan terletak pada ramuan tetapi kepada zikrullohnya. Inilah perbedaannya dengan pengobatan yang dilakukan oleh dukun.

\section{d. Pengobatan Bagi Ibu Hamil}

Beberapa kejadian, ada ibu hamil yang akan melahirkan merasa takut, takut sendirian, takut akan melahirkan dan setelah anak lahir si ibu tidak peduli kepada anaknya dan kadang membenci anaknya yang lahir tersebut, tidak mau menyusukan. Kejadian seperti itu terjadi karena pengaruh syetan atau dalam istilah kampungnya Antu Jaek. Pengobatan pasien yang mengalami keluhan seperti hal di atas oleh Ongku Boncah di buatkan minyak dari pelbagai ramuan untuk dioleskan terutama pada sore hari dipergantian siang ke malam.

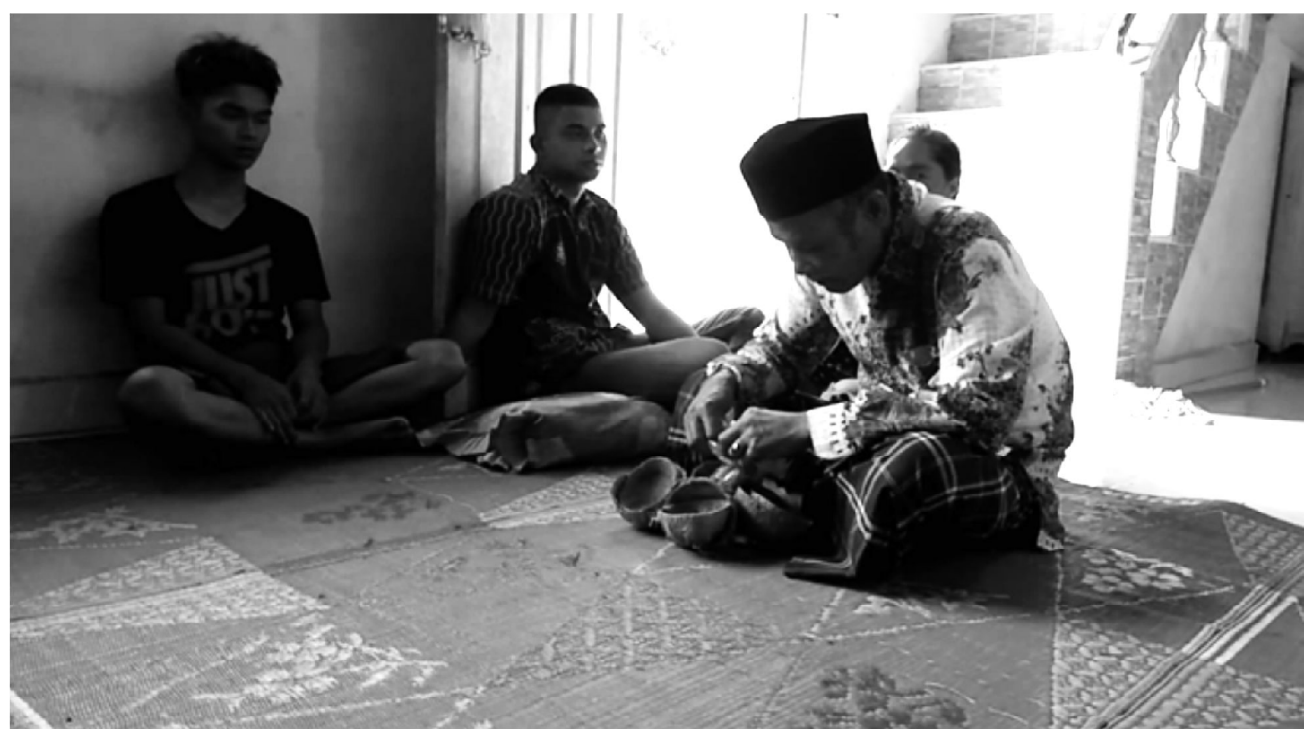

Foto 3: Ongku Boncah Sedang Mendoakan Ramuan

\section{Pengobatan Tradisional di Surau Suluk Buya Edison Kasim}

\section{1) Sekilas Kehidupan Buya Edison Kasim}

Edison Kasim, lahir di Tolang Maua, Kabupaten Lima Puluh Kota pada tanggal 8 Juli 1956. Masa kecilnya dilalui di kampung halamannya seperti anak seusianya. Setelah menamatkan pendidikan dasar di kampungnya, Edison melanjutkan pendidikannya ke Madrasah Tarbiyah Islamiyah (MTI) Koto Panjang Lampasi di Payakumbuh selama tujuh tahun. Ijazah Edison di MTI di tanda tangani oleh Buya Rusli Abdul Wahid selaku Pimpinan Persatuan Tarbiyah Islamiyah (PERTI). Setelah tamat di MTI Koto Panjang Lampasi, Edison melanjutkan 
ke bangku kuliah di IAIN SUSQO di Pekan Baru, Riau di Fakultas Dakwah. Bangku perkuliahan hanya di duduki Edison selama tiga tahun, jenjang pendidikan strata satu tidak bisa diselesaikannya karena berbagai kendala, termasuk kendala ekonomi.

Selain mempelajari ilmu syariat, Edison juga mempelajari beberapa jenis ilmu tarekat. Tarekat pertama yang di pelajarinya adalah Tarekat Saman kepada Haji Ludin di Tolang Maua, waktu itu ia duduk di kelas 6 Sekolah Dasar. Tarekat berikutnya yang dipelajari Edison adalah Tarekat Naqsyabandiyah kepada Ongku Tobek di Koto Panjang Lampasi, sewaktu menempuh pendidikan kelas 6 di MTI Koto Panjang Lampasi. Kelanjutan pelajaran Tarekat Naqsyabandiyah yang berupa suluk/khalwat dilaksanakan Edison di surau tangah di Tolang Maua.

Waktu pelaksanaan suluk/khalwat itu Edison ditimpa sakit. Untuk mendapatkan kesembuhan Edison dibawa berobat ke Syekh Haji Amin di Taeh Bukit. Beberapa lama berobat akhirnya sembuh. Pertemuan Edison dengan Syekh Haji Amin yang awalnya bertujuan untuk berobat akhirnya berlanjut kepada hubungan guru dengan murid. Dari Syekh Haji Amin Edison mempelajari Tarekat Ashaliyah. Mengenai Tarekat Ashaliyah ini juga dipelajari Edison kepada Angku Mudo Juli di Tolang Maua. Sewaktu berada di Pekan Baru, Edison juga belajar Tarekat Syatariah kepada Angku Kuniang Syahrul Luthan. Antara Tarekat Syatariah dan Tarekat Ashaliyah mempunyai kedekatan kajian. Tarekat Ashaliyah berasal dari Tarekat Syatariah. Tarekat Syatariyah lebih dikenal di daerah Pariaman, sedangkan Tarekat Ashaliyah lebih di kenal di daerah Lima Puluh Kota. Tarekat lainya yang dipelajari adalah Tarekat Nabi Khaidir dari Haji Damanhuri di Taeh. Tarekat ini termasuk tarekat yang langka. Tarekat ini dipelajari Buya Edison waktu dia tinggal di Tolang Maua.

Tahun 1983 Edison meninggalkan Pekan Baru, pulang kampung ke Tolang Maua, setelah tinggal di Pekan Baru selama empat tahu. tahun 1984 Edison mulai merintis mendirikan surau yang diberi nama Surau Khalilullah di kampungnya di Talang Maua. Cukup lama Buya Edison mengajarkan tarekat, khalwat/suluk dan pengobatan mulai tahun 1984 sampai tahun 2012 di Tolang Maua. Pernah juga dalam waktu tidak berapa lama membuka praktik pengobatan di Padang Arai Guguak. Kemudian pindah ke Ketinggian Sarilamak Tanjung Pati. Pada tempat baru ini. Buya Edison mendirikan surau yang namanya sama dengan surau di Tolang Maua, yaitu Surau Khalilullah. Pelaksanaan Khalwat/Suluk rutin setiap bulan puasa, kadang ada tambahannya sepuluh hari menjelang Hari Raya Haji. 


\section{2) Praktik Pengobatan Tradisional}

Buya Edison mempelajari pengobatan tradisional dari beberapa orang guru diantaranya Syekh Haji Amin di Taeh Bukit, Angku Mudo Juli di Tolang Maua, Qasim, dan Rina. Dua yang disebutkan terakhir adalah kakek dan neneknya. Menurut buya Edison ilmu pengobatannya yang dipraktikkannya tidak semuanya dipelajari kepada guru, tetapi ada juga yang sifatnya laduni.

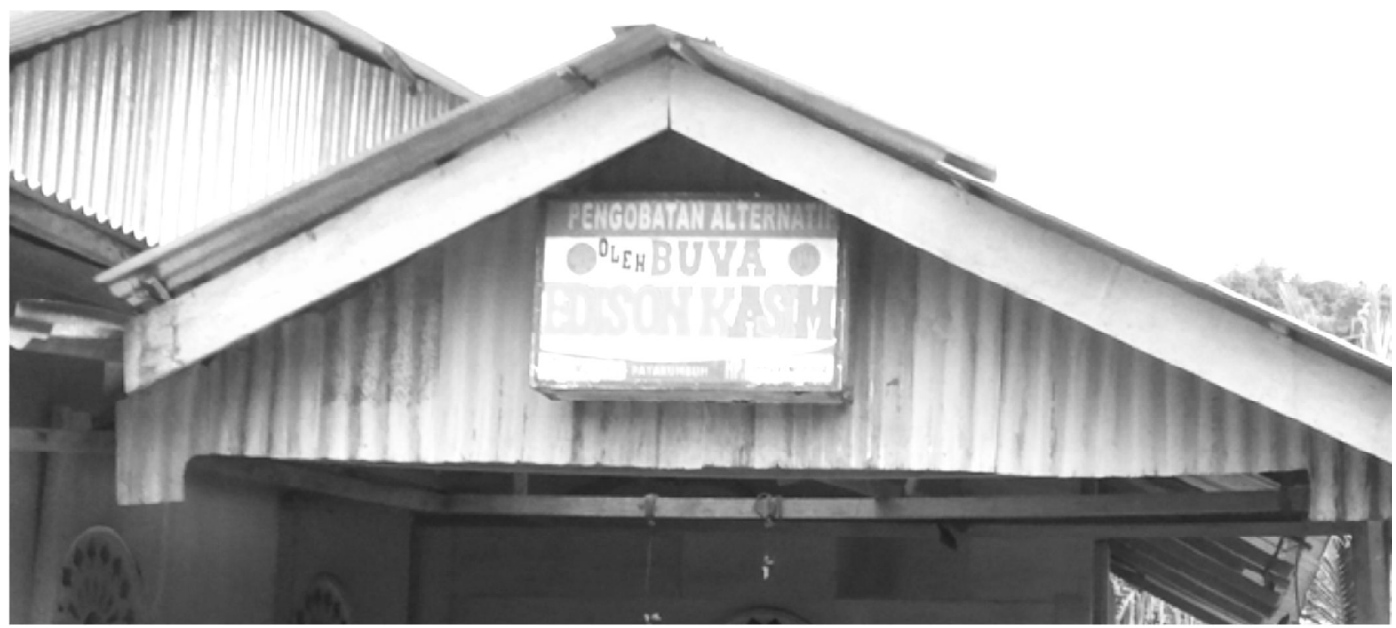

Foto 4: Plank Merek Pengobatan Buya Edison Kasim

Pengobatan pasien yang mengidap penyakit jasmani seperti stroke atau penyakit sejenisnya untuk perawatannya hanya rawat jalan, setelah pasien di doakan dan dizikirkan diberi berbagai macam ramuan. Pasien boleh pulang, bila obat sudah habis pasien datang lagi, biasanya pasien datang sekali semingu. Untuk pasien penyakit rohani, seperti kesurupan, gila, stress, kecanduan narkoba, menghisap lem maka penanganannya rawat inap, tanpa didampingi keluarga pasien. Setiap pasien gangguan jiwa yang akan dirawat, pihak keluarga atau ahli waris yang menyerahkan di wajib membuat surat penyataan. 


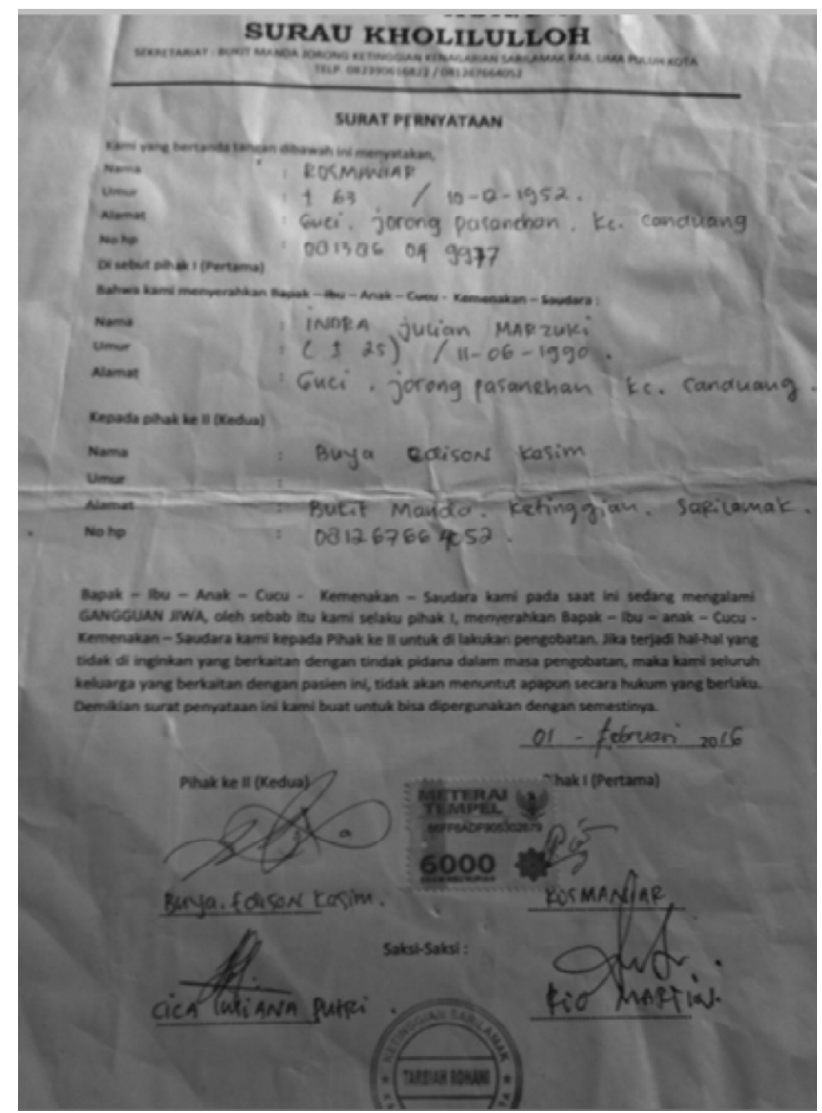

Foto 5: Surat Penyerahan Pasien

Hal penting yang ditanya oleh Buya Edison berkaitan dengan penyakit pasien gangguan jiwa adalah, sebab gangguan jiwa dan sudah berapa lama dirawat di rumah sakit jiwa. Pasien gangguan jiwa yang sedang menjalani pengobatan dijauhkan dari keluarga untuk sementara waktu. Tujuanya agar pasien dapat fokus menjalani pengobatan. Bila pasien telah menampakkan kemajuan kesehatan, maka keluarga pasien diminta datang untuk mengunjungi. (Wawancara dengan Buya Edison pada hari Senin tanggal 27 Maret 2017 di Ketinggian Sarilamak).

\section{3) Pandangan Buya Edison Mengenai Penyakit Jiwa}

Menurut Buya Edison penyakit gangguan jiwa yang terjadi kepada manusia karena beberapa faktor, sebagai berikut:

a. Gangguan Jiwa Karena Gangguan Jin.

Pertanda orang yang sakit karena gangguan jin/syetan adalah datangnya penyakitnya berwaktu waktu, misalnya jam 4 kambuh penyakitnya, atau jam 12 atau jam 9 pagi. Masuknya jin/syetan kedalam tubuh manusia, bisa karena diutus oleh 
pengirim sihir dan bisa juga karena jin/syetan merasa terganggu oleh prilaku manusia. Orang yang kemasukan jin ujung jari kaki dan jari tangan dingin.

\section{b. Gangguan Jiwa Karena Termakan Ramuan}

Gangguan jiwa karena termakan ramuan ini termasuk kedalam sihir. Ada benda-benda tertentu yang diramu oleh dukun ilmu ilmu hitam yang bisa membuat. Orang yang memakannya akan terganggu jiwanya. Ramuan tersebut membuat orang menjadi bodoh. Buya Edison menceritakan pernah kejadian pasien yang diobatinya bertingkah aneh, pasien tersebut mau bergerak kalau di lehernya dipasang tali, dan ditarik seperti menarik kera.

\section{c. Gangguan Jiwa Karena Stress}

Gangguan jiwa karena stress dalam menghadapi masalah kehidupan. Buya Edison menceritakan pasiennya dari Bangka Belitung yang stress karena tidak kuat menghadapi persoalan rumah tangga. Saat jiwanya terganggu, pasien tersebut mengganggu orang-orang yang ada disekitarnya. Keluarganya memutuskan untuk memasung dan menempatkannya ditempat yang jauh dari keramaian masyarakat. Waktu keluarganya mengantar berobat ke sini, kakinya lumpuh karena sudah lama dipasung. Proses pengobatan dilaluinya disini, setelah itu tahap pendidikanpun dilaluinya, Alamdulillah sekarang sudah sehat kembali. Sebelum sakit dia berprofesi sebagai tukang bangunan. Setelah lebih satu tahun disini jasmani dan rohaninya sudah sehat kembali. Sebagian dari bangunan rumah dan surau Buya Edison dilakukan oleh pasien. Sampai sekarang pasien tersebut sudah lima tahun tinggal disini. (Wawancara dengan Buya Edison pada hari Senin tanggal 27 Maret 2017 di Ketinggian Sarilamak).

\section{d. Gangguan Jiwa Karena Geger Otak}

Gangguan jiwa karena geger otak disebabkan kecelakaan. Menurut Buya Edison Gangguan jiwa seperti ini sulit untuk disembuhkan sebab ada syaraf syaraf yang rusak karena kecelakaan yang dialami.

\section{4) Program Pengobatan Penyakit Jiwa}

Program pengobatan penyakit jiwa yang diprogramkan Buya Edison selama empat puluh hari, dengan langkah langkah sebagai berikut: 


\section{a. Membersihkan Perut}

Langkah pertama adalah membersihkan perut dengan cara di diluntur atau di ruruah dengan ramuan obat untuk membersihkan perut dengan cara diminum. Sekitar lima menit setelah meminum ramuan tersebut, isi perut akan keluar melalui buang air besar dan muntah. Setelah pasien buang air besar dan muntah sekitar lima belas kali atau diperkirakan isi perut pasien sudah keluar, maka diminumkan penangkal sehingga buang air besar dan muntah berhenti.

Pembersihan perut dari berbagai kotoran yang merugikan kesehatan tubuh sangat perlu dilakukan. Buya Edison menjelaskan bagaimana peran kotornya perut sebagai penyebab sakitnya tubuh manusia. Disamping diminumkan, saripati ramuan juga diteteskan kedalam rongga hidung. Tujuannya adalah untuk membersihkan rongga kepala dari kotoran. Berbagai kotoran yang ada dirongga kepala akan dikeluarkan oleh ramuan tersebut, terutama yang disebabkan oleh menghisap lem. Proses pembersihan ini akan menyebabkan pasien menjadi lemah.

Apabila tubuh sudah bersih, dan tenaga pasien sudah pulih dan tidak meronta atau melawan, pasien didudukkan dan dizikirkan dengan kalimat Laa Ilaha Illalloh. Apabila di zikirkan orang yang tersebut akan menjadi tenang. Zikir pengobatan dirutinkan sekurang kurangnya 100 kali setiap setelah sholat. Jadi untuk lima waktu adalah lima ratus kali dengan kalimat Laa Iaha Illalloh. Biasanya untuk subuh agak lebih panjang, sekurang-kurangnya zikir sebanyak tiga ratus kali, sholawat tafrijah atau sholawat nariyah dan tawajuh untuk melatih konsentrasi. Pasien disuruh untuk memandang dada sebelah kiri dan membaca kalimat Allah Allah. Sepanjang proses itu pasien senantiasa dalam pengawasan. Bila dalam mentawajjuhkan terjadi dompakan antara yang mentawajjuhkan dengan pasien maka besar harapan pasien akan sembuh. Dompakan bisa diartikan sebagai respon pasien sewaktu proses menzikirkan pasien. Bila respon itu sudah terjadi, maka kepercayaan diri pasien sudah mulai tumbuh yang harus dipertahankan adalah bagaimana pasien tadi tidak lupa dengan dirinya. Bila pasien mengabaikannya besar kemungkinan akan sakit kembali. Bila ilmu tentang zikir itu senantiasa di amalkan mudah mudahan penyakit tidak lagi kembali. 
b. Batangeh

Proses pengobatan berikutnya pasien di tangas (mandi uap dengan rempah). Waktu pelaksanaan tangeh ini memasuki minggu kedua pengobatan. Tujuan tangas ini adalah untuk membuka pori-pori dan merangsang syaraf-syaraf yang ada pada seluruh tubuh. Setelah itu pasien dikasih ramuan untuk merangsang selera makan. Ramuannya terbuat dari lempuing, kunyit temu, kunyit bolai, kunyit temberang, kunyit biasa, kunyit nan gondo. Biasanya setelah setelah meminum ramuan olahan bahan tersebut selera makan pasien akan menjadi baik. Hal itu akan baik untuk proses perbaikan sel-sel tubuh pasien. Proses pengobatan dengan zikir jalan terus lima kali sehari semalam setiap selesai shalat.

\section{c. Babokam}

Terapi bokam (mengeluarkan darah kotor dari permukan kulit) tidak berlaku umum bagi pasien gangguan jiwa bergantung kepada kondisi fisik pasien. Bagi pasien yang fisiknya kuat, badannya gemuk dan banyak noda-noda hitam di tubuhnya maka dilakukan terapi bokam. Sedangkan pasien yang terlihat lemah tidak dilakukan bokam. Tujuan bokam adalah untuk membuang darah kotor dari tubuh pasien.

\section{d. Mandi Fajar}

Setelah empat belas hari pasien menjalani pengobatan, pada hari ke lima belas, pasien dimandikan diwaktu sebelum fajar, sebelum waktu subuh. Mandi fajar ini sekurang kurangnya selama 21 hari. Menurut Buya Edison ada 72 penyakit yang dapat dicegah dengan mandi sebelum fajar. Bila dalam masa empat puluh hari, setelah menjalani tahapan-tahapan pengobatan. Pasien menunjukkan perkembangan kesehatan yang baik, proses berikutnya adalah masa pendidikan.

\section{5) Program Pendidikan}

Program masa pendidikan ada yang tiga bulan, enam bulan, satu tahun dan ada juga tiga tahun. Program pendidikan yang akan diikuti bergantung pasien dan keluarga. Pada tahap pendidikan ini pasien diajarkan shalat dan ilmu zikir dan ilmu mengenal diri. 
Ilmu zikir yang diajarkan berdasarkan Tarekat Saman. zikrullah itu menjadikan hati tenang. Orang yang sedang terganggu jiwanya hatinya tidak tenang, emosiya tidak stabil, terjadi kegoncangan jiwa. Dengan dididik untuk zikrullah, maka jiwa pasien akan semakin baik.

Menurut Buya Edison, Tarekat Saman bila diamalkan berdampak baik untuk kesehatan. Berbagai benyakit yang ada seperti penyakit dada, di perut dan di tempat lainnya bisa dihancurkan dengan zikir. Zikir dalam Tarekat Saman juga bisa menjadi olah raga bagi tubuh manusian. Selain itu zikir dalam Tarekat Saman juga bisa menghancur istana syetan di dalam tubuh manusia. Bila kondisi pasien sudah membaik, pasca pengobatan selama empat puluh hari, pasien disuruh beraktifitas fisik seperti berjalan tanpa alas kaki, olah raga dan diajarkan bekerja.

\section{6) Ramuan Pengobatan}

Ramuan obat-obatan yang digunakan oleh Buya Edison adalah ramuan yang di racik sendiri. Tumbuh-tumbuhan yang digunakan ada yang ditanam dan ada juga yang dicari di sekitar lingkungan dan ada juga yang dicari ke Bukit Bongsu.

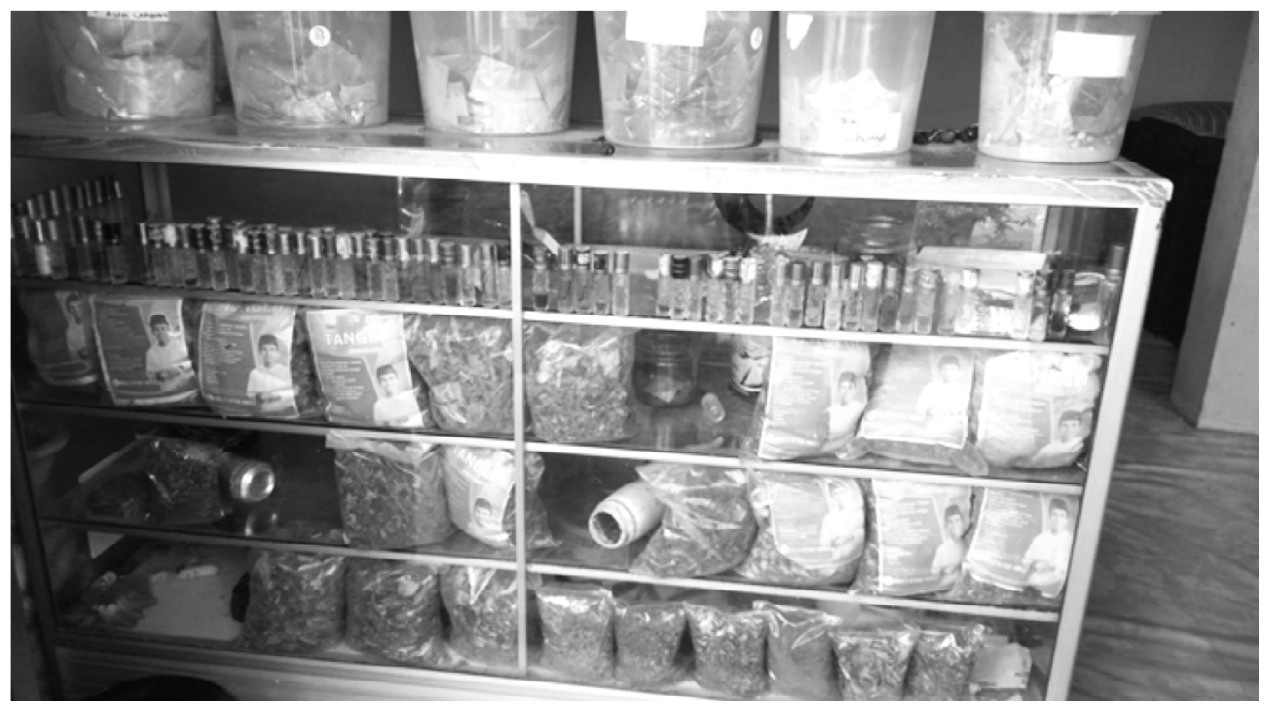

Foto 6: Ramuan Obat

Ramuan obat yang di racik sendiri oleh Buya Edison ada yang obat luar dan ada juga obat untuk di makan atau diminum. Obat untuk bagian luar seperti ramuan rempah untuk bertangas dan obat penyakit kulit. Sedangkan obat untuk dimakan seperti obat pembersih perut dan lainnya. 


\section{7) Penyakit fisik}

Macam macam penyakit berkaitan dengan fisik yang biasa ditangani seperti maag kronis, sakit perut, sakit kepala, penyakit kulit, kanker, sulit mendapatkan keturunan, stroke, ayan dan lainnya. Beberapa penyakit dideteksi dengan menggunakan metode bedah ayam.

\section{8) Doa}

Lafal doa yang dibacakan saat pengobatan di dasarkan kepada al Quran dan hadits nabi. Namun demikian, ada juga doa dalam pengobatan yang disusun seperti bait-bait pantun sebagaimana berikut:

Apuang apuang si apang apang.

Tabang buruang kamanaro.

Bumi Tagantuang langik tasampag dengan kudarat Allah juo, kununlah panyakikko.

(kuasa menghilangkan penyakit kembalikan kepada qudrat Allah, bukan berada di tangan manusia).

\section{Doa Untuk Mandi}

Sabantoro namonyo aia,

Aia zat dilingkuang zat sabatang tubuah

Nan berulu dari Allah

Bamuaro ka Muhammad alirannyo batang tubuah

Barakaik La ilaha illallah

(Wawancara dengan Buya Edison pada hari Senin tanggal 27 Maret 2017 di

Ketinggian Sarilamak).

\section{Pengobatan Tradisional di Surau Suluk Buya Belubus}

\section{1) Sekilas Mursyid Suluk di Surau Suluk Belubus}

Surau Suluk di Belubus didirikan oleh Syekh Muda Abdul Qodim (SMAQ). Beliau meninggal tahun 1957. Selanjutnya aktifitas pengelolaan surau dilanjutkan oleh kemenakan beliau, Syekh Mukhtar Angku Tanjuang. Setelah itu pengelolaan surau dilanjutkan oleh Dt Bangso Dirajo, kemenakan Angku Tanjuang dan buya Anas Malik.

Semenjak tahun 2011 Mursyid Suluk di Surau Belubus di emban oleh Yaman Khatib. Hubungan keturunan Yaman Khatib dengan SMAQ adalah Ayah SMAQ merupakan datuk 
sepesukuan beliau. Yaman Khatib adalah anak dari Habib Ongku Rancak seorang yang sangat dekat dengan Syekh Muda Abdul Qodim. Menurut Yaman Khatib untuk mengemban sebagai pelanjut mursyid suluk di surau Belubus ini amat berat, karena surau ini adalah salah satu surau tuo yang masih banyak dikunjungi oleh jamah dari pelbagai tempat. Jamaah yang hadir sering bertanya berkaitan dengan pelbagai permasalahan.

Yaman Khatib dilahirkan di Belubus 75 tahun yang lalu. Ayahnya, Ongku Rancak adalah orang dekat sekaligus murid dari Syekh Muda Abdul Qodim . Habib Ongku Rancak semenjak umur tujuh tahun telah tinggal bersama Syekh Muda Abdul Qodim. Oleh karena itu secara emosional beliau sangat dekat dengan SMAQ.

Keseharian orang tua Yaman sering di surau membantu kegiatan buya, Yaman kecilpun banyak menghabiskan masa-masa kecilnya di Surau Belubus mengikut orang tuanya. Yaman Khatib menceritakan

Orang tua laki-laki saya semenjak umur tujuh tahun sudah tinggal dengan buya di sini. Saya sejak kecil makan nasi orang suluk, bila saya tidak datang ke surau orang tua membawakannya ke rumah.

(Wawancara dengan Buya Yaman Khatib pada hari Kamis tanggal 30 Maret 2017 di Belubus).

Setelah tamat dari sekolah raknyat Yaman Muda mengikuti tes untuk menjadi anggota polisi. Beliua dinyatakan lulus dan mulai bertugas pada tahun 1965, tahun yang sama dengan terjadinya peristiwa G 30 S/PKI. Dinas di kepolisian beliau jalani sampai tahun 1990.

\section{2) Pengobatan Tradisional yang Dilakukan}

Buya Yaman Khatib mengatakan bahwa untuk pengobatan beliau kurang mendalami. Untuk pengobatan Syekh Mudo Abdul Qodim memang menguasai. Orang tuanya, Habib Ongku Rancak pun seperti itu. Mengenai ilmu pengobatan itu, oleh orang tuanya akan diajarkan. Tapi waktu itu Yaman muda tidak tertarik.

Kalau ada yang meminta obat biasanya buya Yaman Khatib merekomendasikan untuk berobat kepada salah seorang murid dalam suluk. Muridnya itu mengetahui banyak tentang pengobatan tradisional. Namun demikian menurut Buya Yaman Khatib bila ada yang meminta obat maka ada beberapa kuncinya sebagai berikut: 
a. Orang yang akan berobat yakin dengan orang yang akan membantu pengobatan.

b. Ramuan obat apa yang teringat dan sesuai dengan bisikan hati yang pertama.

c. Hubungan dengan pencipta harus senantiasa dijaga.

Orang yang datang berobat ke Surau Belubus ada saja setiap hari. Penyakit yang dideritapun berbagai macam. Orang yang datang berobat itu ada yang bersedia menuruti saran Buya Yaman Khatib agar berobat kepada muridnya, ada juga yang tidak bersedia. Ada orang yang meminta kesedian buya Yaman khatib langsung yang mengobatinya seperti seorang pemuda dari Nagari Sariak Laweh yang menderita penyakit akibat di sihir atau diguna guna.

Ketika wawancara dengan buya Yaman Khatib sedang berlangsung, di pelataran penerimaan tamu Surau Belubus terdengar suara motor yang cukup keras menuruni jalan surau dan berhenti tidak jauh dari kami. Seorang pemuda berbadan gempal, berbaju hitam dan bercelana pendek memarkir motornya. Saat itu buya Yaman Khatib memberi tahu bahwa itulah orang yang baru saja diceritakannya. Beberapa saat pemuda tersebut telah duduk didekat kami. Saya coba menggali lebih dalam informasi mengenai dirinya. Pemuda itu menjelaskan.

Saya sehari hari bekerja sebagai sopir mobil penumpang trayek Kota PayakumbuhSariak Laweh. Penyakit yang saya derita adalah akibat di guna-guna karena persoalan muda mudi. Orang yang membuat guna untuk saya melalui baju. Sewaktu saya diobati oleh buya di dalam qubah (bangunan yang di dalamnya kuburan SMAQ) nampak bagi saya baju tersebut di asap. Pada waktu waktu tertentu badan saya terasa panas dan sangat sulit untuk tidur. Saya sering datang kesini. Menjelang hari raya haji kemaren selama 20 hari saya di sini. Kadang saya ke sini hanya untuk bertemu buya, minum air sumur kemudian pergi. Alhamdulillah kondisi saya sudah jauh lebih baik.(Wawancara dengan pemuda pasien Buya Yaman Khatib pada hari Kamis tanggal 30 Maret 2017 di Belubus).

Buya Yaman Khatib menceritakan diantara ramuan obat yang diberikan kepada pasien yang meminta obat adalah air sumur surau. Masyarakat sekitar juga banyak yang mengambil air untuk keperluan obat. Bila datang peziarah dari medan dan sekitarnya, biasanya masingmasing mereka akan membawa satu dirigen yang berisi 20 liter. Salah seorang dari peziarah itu pernah bercerita bahwa dia membuat sumur di rumahnya di Medan, air sumur tersebut tidak bagus. Waktu datang ke sini, diambilnya air sumur ini satu botol aqua besar, dimasukkan nya kedalam sumurnya di medan. Air sumur yang semula tidak bagus menjadi bagus seperti air sumur ini. 


\section{PENUTUP}

Surau Suluk, Mursyid dan pengobatan tradisional adalah tigal komponen yang saling berkaitan. Mursyid Suluk mendirikan surau sebagai tempat beribadah dan tempat membimbing murid dalam berjalan mendekatkan diri kepada Allah. Para murid dan masyarakat meyakini bahwa seorang Mursyid Suluk adalah hamba yang sholeh dan dekat dengan Allah, dengan demikian doa dan pintanya diyakini dikabulkan Allah. Keyakinan seperti itu yang mendorong murid dan masyarakat percaya bahwa mursyid suluk mampu untuk membantu menyelesaikan masalah yang dihadapi, berkaitan dengan berbagai penyakit yang diderita.

Pengobatan tradisional yang dilakukan oleh Mursyid Suluk didasarkan kepada nilai nilai al Quran dan sunnah. Kekuatan pengobatan tertumpu kepada zikir, baik zikir dalam Tarekat Saman atau dalam Tarekat Naqsyabandiyah. Pengobatan untuk penyakit gangguan jiwa dan penyakit non medis lebih banyak ditangani dibandingkan penyakit yang bersifat medis. Ramuan obat bukanlah menjadi utama, hal utama adalah zikrullah. Ramuan obat yang digunakan ada yang dipelajari dan ada juga yang bersifat laduni. Ramuan yang bersifat laduni dikaitkan dengan sesuatu yang teringat dan sesuai dengan bisikan hati yang pertama. Keyakinan akan pertolongan Allah merupakan Syarat yang harus dimiliki orang yang akan berobat dan juga yakin dengan orang yang akan membantu pengobatan. Hubungan baik dengan pencipta harus senantiasa dijaga.

\section{DAFTAR PUSTAKA}

Akhiruddin, K.M. 2015. Lembaga Pendidikan Islam di Nusantara. Jurnal Tarbiya Vol 1 No 1

Azra, Azyumardi. 2004. Jaringan Ulama Timur Tengah dan Kepulauan Nusantara Abad XVII \& XVIII, Jakarta: Kencana

Bungin, Burhan. 2007. Penelitian kualitatif: Komunikasi, Ekonomi, Kebijakan Publik, dan Ilmu Sosial Lainnya. Jakarta: Kencana

Bruinessen, Martin van. 1995. Kitab Kuning, Pesantren dan Tarekat: Tradisi-Tradisi Islam Indonesia. Bandung: Mizan

Dobbin, Christine. 2008. Gejolak Ekonomi, Kebangkitan Islam, dan Gerakan Padri, Minangkabau, Terjemahan oleh Lilian D. Tedjasudhana. Depok: Komunitas Bambu

Kusmayadi dkk, 2000. Metodologi Penelitian dalam Bidang Kepariwisataan, Jakarta: PT Gramedia Pustaka Utama

S.Wiranta dan H.Hadisuwarno, 2007.Modul Diklat FungsionalPeneliti Tingkat Pertama, Cibinong: LIPI 
Sagimun, MD, 1993 “Mengapa Biografi” dalam Suaji Syafi'i (ed). 1993. Pemikiran Biografi dan Kesejarahan. Jakarta: Gramedia

\section{DAFTAR INFORMAN}

1. Buya Alisani Ongku Boncah, 66 tahun, Alamat Taeh Baruah

2. Buya Edison Kasim, Alamat Koto Tinggi Sarilamak

3. Buya Zed, 58 tahun, Alamat Koto Tuo Mungka

4. Buya Yaman Habib, 74 tahun, Alamat Belubus

5. Boni Purnama 41 tahun, Alamat Koto Nan Empat Payakumbuh

6. Apria Putra, 32 tahun, Alamat Mungka

7. Pasien Buya Yaman Khatib, 28 tahun, Alamat Sungai Balantiak 